\title{
Leaching of Pervious Concrete Produced Using Mixed Recycled Aggregates
}

\author{
Rafael Jansen Mikami ${ }^{1 *}$ \\ https://orcid.org/0000-0002-4859-5344
}

Ana Carolina Barbosa Kummer ${ }^{2}$

https://orcid.org/0000-0002-9415-3029

\section{Maria Magdalena Ribas Döll ${ }^{1}$ \\ https://orcid.org/0000-0002-6648-1607}

${ }^{1}$ State University of Ponta Grossa, Department of Civil Engineering, Ponta Grossa, Paraná, Brazil; ${ }^{2}$ Midwestern Parana State University, Department of Environmental Engineering, Irati, Paraná, Brazil.

Received: 2018.08.03; Accepted: 2019.09.17.

*Correspondence: rjmikami@uepg.br; Tel.: +55-42-32203074 (R.J.M.)

\section{HIGHLIGHTS}

- Recycled aggregates were used to produce pervious concrete.

- Chromium and cadmium leached in recycled aggregate concretes.

- $\mathrm{Cr}$ and sulfates leaching was higher in concrete produced with ceramic aggregate.

Abstract: Waste produced by the construction sector is a problem that has grown over the last few years. Construction and demolition waste makes up about $50 \%$ by mass of the total solid waste produced in Brazil. One alternative by which to reduce this volume is recycling this material in the form of aggregates. However, it is necessary to analyze the environmental risk that the use of recycled aggregates can entail for adjacent soil and the water table. The purpose of this work was to evaluate pervious concrete samples that contained recycled aggregates and to subject them to leaching tests. The results were compared with the limits established by the Italian methodology. Aggregates with 10, 25, 50, and 100\% ceramic were used, as well as a recycled concrete aggregate and a natural aggregate. With the exception of the $25 \%$ ceramic trial, all the treatments introduced chromium to the water in which they were immersed, with accumulated concentrations varying from 0.009 to $0.099 \mathrm{mg} \mathrm{L}^{-1}$. Cadmium was found in higher quantities, with cumulated concentrations between 0.104 and $0.417 \mathrm{mg} \mathrm{L}^{-1}$. Sulfate concentrations were higher after $24 \mathrm{~h}$ of immersion, with a maximum release of $71.7 \mathrm{mg} \mathrm{L}^{-1}$. The concrete made with $100 \%$ ceramic aggregate leached more chromium and sulfate than the other aggregates.

Keywords: pervious pavement; CDW; porous concrete; ceramic content; water pollution.

\section{INTRODUCTION}

Civil construction is a sector that produces a significant amount of waste, accounting for a large part of total solid waste generation worldwide. In particular, construction and demolition waste (CDW) makes up more than $30 \%$ by mass of all solid waste generated in Europe [1]. In Brazil, CDW accounts for about $50 \%$ by mass of all solid waste produced, totaling 45 million tons per year [2]. 
CDW production has become an issue in many countries, leading them to require the allocation of areas for the deposition of these materials. For example, construction waste in Brazil is taken to specific landfills where it is recycled and stored until it can be used [3]. For this reason, the use of CDW as a recycled aggregate is being studied [4]. In addition, this would avoid the extraction and grinding process of natural aggregates, resulting in decreased consumption of energy and lower $\mathrm{CO} 2$ emissions [5].

The high availability and low cost of natural aggregates often impede the search for alternative materials [6]. However, the increasing use of natural resources causes local shortages, leading to the need for the materials to be transported and for a corresponding increase in price. With time, CDW could become a more viable option for recycled aggregate production.

Countries like Denmark, Estonia, Germany, and England recycle up to $75 \%$ by mass of all CDW produced [7]. Even though Brazil has an installed capacity to recycle up to $46 \%$ of the volume of CDW generated, it is estimated that only $21 \%$ is used in aggregate production [8].

CDW consists of waste generated from construction, demolition, and renovation activities. The vast majority of CDW comes from building demolitions. However, new construction also generates waste [5]. This waste is mainly composed of concrete fragments, brick, and ceramic materials; however, depending on the type of activity that is being performed and the materials used, different kinds of waste, including wood, glass, plastic, metals, and soils, can be found $[9,10]$.

CDW can also be used as a recycled aggregate for pervious concrete production. Pervious concrete is a material that has a pore volume of about 15 to $35 \%$, which allows water to drain through its interior [11, 12]. Tennis, Leming and Akers [13] affirms that because of this property, pervious concrete is an alternative for urban drainage systems. Reduction of runoff, groundwater recharge, and ambient temperature balance are some of the advantages of using this material [13].

The aggregate used in pervious concrete usually has a uniform particle size distribution, as this property yields a higher pore volume and ensures greater concrete permeability $[14,15]$. The grain size of the aggregate can vary. Nonetheless, aggregates with uniformed larger dimensions provide this material with higher permeability $[15,16]$. The most commonly used aggregates are those with dimensions between 1.18 and $19 \mathrm{~mm}$, as determined using standardized sieves over a range of mesh sizes [13]. Results obtained by Ramezanianpour and Joshaghani [15] show that aggregates with dimensions from 9.5 to 12.5 $\mathrm{mm}$ can provide concrete with good permeability and compressive strength.

Recycled concrete aggregates (RCAs) and mixed recycled aggregates can release heavy metals because of material leaching when they are used in pavement subbases [17]. The authors found chromium and sulfate after water passed through the aggregate, thereby simulating rainwater percolation. Jacob, Rocha, Cheriaf and Schaefer [18] also confirmed the presence of chromium, arsenic, zinc, and cadmium in leached water from conventional concrete made with recycled aggregates. Studies [19] shows that recycled aggregates with higher contents of ceramic tend to release higher quantities of chromium and sulfate. The main cause for pollutant release is contact with rainwater, which provokes leaching [20]. Although the mechanical performance of concrete containing waste has been studied [21], few studies have evaluated its environmental impact.

In this sense, the purpose of this study was to analyze the quality of water leached from pervious concrete made with recycled aggregates containing ceramic material. Multiple incubation times were employed to yield as complete a picture as possible.

\section{MATERIAL AND METHODS}

\section{Recycled aggregates}

For this study, five recycled aggregates and one natural aggregate were used to produce pervious concrete. The recycled aggregates were produced by mixing crushed ceramic bricks with CDW from a local recycling plant. The amount of ceramic material was adjusted to $10,25,50$, and $100 \%$ of the total, corresponding to the treatments RA10, RA25, RA50, and RA100, respectively. The remaining treatments were characterized by the use of a natural aggregate of basaltic origin (NABO) and an RCA, obtained from crushing concrete samples. The aggregates were mechanically sifted to suit a uniform grain distribution between 9.5 and $12.5 \mathrm{~mm}$. The chemical composition of the aggregates and cement paste were analyzed by X-ray fluorescence (XRF), as displayed in Table 1. 
Table 1. Chemical composition of the aggregates and cement paste, as determined by XRF

\begin{tabular}{ccccccccccc}
\hline Material & $\mathrm{SiO}_{2}$ & $\mathrm{Al}_{2} \mathrm{O}_{3}$ & $\mathrm{Fe}_{2} \mathrm{O}_{3}$ & $\mathrm{SO}_{3}$ & $\mathrm{~K}_{2} \mathrm{O}$ & $\mathrm{TiO}_{2}$ & $\mathrm{CaO}$ & $\mathrm{MnO}$ & $\mathrm{ZnO}$ & $\mathrm{SrO}$ \\
\hline Natural Aggregate & 34.25 & 11.34 & 28.67 & 1.00 & 2.12 & 4.38 & 17.62 & 0.40 & 0.09 & 0.12 \\
Concrete Waste & 30.85 & 8.25 & 20.79 & 1.53 & 1.88 & 3.37 & 32.55 & 0.56 & 0.06 & 0.17 \\
Ceramic Brick Waste & 49.23 & 24.65 & 16.67 & 1.73 & 4.26 & 2.19 & 1.01 & 0.22 & 0.05 & 0.00 \\
CDW & 39.97 & 7.12 & 8.22 & 1.83 & 3.98 & 1.52 & 37.11 & 0.20 & 0.06 & 0.00 \\
Cement Paste & 8.98 & 1.96 & 6.05 & 2.06 & 0.70 & 0.77 & 78.90 & 0.51 & 0.07 & 0.00 \\
\hline
\end{tabular}

\section{Pervious concrete}

The physical properties and leaching characteristics of the pervious concrete were evaluated. Each treatment underwent five replications. The concrete was obtained by mixing cement, coarse aggregate, and water; sand was not added. The pervious concrete was produced with CPII F-32 Brazilian Portland cement. The cement to aggregate ratio by mass was $1: 5$, and the water to cement ratio was 0.30 . The concrete was molded into cylindrical samples of $5 \phi \times 5 \mathrm{~cm}$, which were compacted with a socket. The samples were left outdoors for a curing period of 28 days, after which a leaching test was performed. Wet curing practices were not used in order to avoid concrete leaching during this period.

\section{Leaching test}

The process for leaching analyses was based on methodology established by Italian legislation [22-24]. The five concrete replicates were immersed in a Becker glass that contained a volume of ultrapure water five times greater than the sample volume (approximately $590 \mathrm{~mL}$ ). They were also kept in a refrigerated incubator at a temperature of $20 \pm 5 \stackrel{\circ}{\circ}$. Ultrapure water characteristics are displayed in Table 2.

The immersion water was periodically changed over a total period of 16 days. The liquid was completely substituted after $24,72,168$, and $384 \mathrm{~h}$ of incubation. At the end of each sampling period, analyses were carried out for each repetition, including $\mathrm{pH}\left(4500-\mathrm{H}^{+} \mathrm{B}\right)$, electrical conductivity $(2510 \mathrm{~B})$, total alkalinity (2320 B), chemical oxygen demand (COD) (5220 D), total solids (2540 B), and sulfate (4500$\mathrm{SO}_{4}{ }^{2-} \mathrm{C}$ ). The analyses were performed using the methodology established by Standard Methods [25].

Table 2. Physical and chemical properties of ultrapure water used for immersing the pervious concrete

\begin{tabular}{|c|c|c|c|c|c|c|}
\hline Replicate & $\mathrm{pH}$ & $\begin{array}{c}\text { Electrical } \\
\text { Conductivity } \\
\left(\mu S . \mathrm{cm}^{-1}\right)\end{array}$ & $\begin{array}{l}\text { Total Alkalinity } \\
\left(\mathrm{mg} \mathrm{CaCO}_{3} \mathrm{~L}^{-1}\right)\end{array}$ & $\underset{\left(\mathrm{mg} \cdot \mathrm{L}^{-1}\right)}{\text { COD }}$ & $\underset{\left(\mathrm{mg} \cdot \mathrm{L}^{-1}\right)}{\mathrm{SO}^{2-}}$ & $\begin{array}{l}\text { Total solids } \\
\left(\mathrm{mg} \cdot \mathrm{L}^{-1}\right)\end{array}$ \\
\hline 1 & 6.43 & 1.15 & 2.0 & 0.0 & 0.0 & 0.0 \\
\hline 2 & 6.17 & 1.27 & 2.0 & 0.0 & 0.0 & 0.0 \\
\hline 3 & 6.36 & 1.09 & 2.0 & 0.0 & 0.0 & 0.0 \\
\hline 4 & 6.18 & 1.06 & 2.0 & 0.0 & 0.0 & 0.0 \\
\hline 5 & 6.15 & 1.06 & 1.0 & 0.0 & 0.0 & 0.0 \\
\hline Average & 6.26 & 1.13 & 1.8 & 0.0 & 0.0 & 0.0 \\
\hline
\end{tabular}

Concentrations of chromium, cadmium, copper, lead, and zinc were determined by flame atomic absorption. Leaching tests were completed immediately after collecting the sample, except for the heavy metals. Three replications were used in order to determine the heavy metal concentrations. These samples were stored for a maximum of five months at room temperature, after acidification with nitric acid down to $\mathrm{pH}<2.0$.

\section{Statistical analysis}

For every time-based sample, the five replications of leachate characterization and three replications of metal concentration analysis were submitted for analysis of variance at a significance level of $5 \%$. Averages were verified by the Tukey test, at a significance level of $5 \%$.

\section{RESULTS AND DISCUSSION}

Table 3 shows the average results for the leachate characterization, presented as the average of the five samples. There were statistical differences between the different concrete samples. The amount of 
ceramic in the recycled aggregate interfered with the $\mathrm{pH}$, electrical conductivity, alkalinity, and sulfate concentration. There was low variation in COD and total solids between the treatments.

\section{Concrete composition and leaching}

The aggregate used for the pervious concrete is covered by a layer of cement paste with interconnected pores. These are formed by the spaces between the grains in the aggregate. On its first contact with water, the cement paste is subject to leaching, which tends to occur more intensely due to the greater surface area of the pervious concrete when compared to conventional concrete.

The hardened cement paste is mainly composed of calcium silicate hydrate (CSH), which is a compound that is not very well defined [26]. About 20 to $25 \%$ of the volume of the cement paste consists of $\mathrm{Ca}(\mathrm{OH})_{2}$ (portlandite), whereas 15 to $20 \%$ of the volume is taken up by calcium sulfoaluminates [27]. This is consistent with the cement paste composition obtained by XRF (Table 1) where $\mathrm{CaO}$ and $\mathrm{SiO}_{2}$ were the main compounds detected.

Concrete leaching happens initially with the dissolution of $\mathrm{Ca}(\mathrm{OH})_{2}$ from the cement paste and the release of $\mathrm{Ca}^{2+}$ and hydroxide ions, thereby increasing porosity [28, 29]. Since portlandite is highly soluble in pure water, it is the most susceptible to leaching [27]. As a consequence, part of the calcium connected to $\mathrm{CSH}$ may also leach. However, these alterations are not significant in the nanoporosity of the solid phase [30]. Leaching of $\mathrm{Ca}(\mathrm{OH})_{2}$ may justify the changes in the physicochemical properties of the water since the first leachate extraction (Table 3).

Table 3. Average results of the physicochemical leachate characterization of the different types of concrete, after immersion in ultrapure water for $24,72,168$, and $384 \mathrm{~h}$

\begin{tabular}{|c|c|c|c|c|c|c|}
\hline Treat. & NABO & RCA & RA10 & RA25 & RA50 & RA100 \\
\hline \multicolumn{7}{|c|}{ pH } \\
\hline $24 \mathrm{~h}$ & $11.59 \mathrm{~b}$ & $11.53 \mathrm{~b}$ & $11.92 \mathrm{a}$ & $11.91 \mathrm{a}$ & $11.37 \mathrm{~b}$ & $10.93 \mathrm{c}$ \\
\hline $72 \mathrm{~h}$ & $11.85 \mathrm{ab}$ & $11.74 \mathrm{~b}$ & $12.07 \mathrm{a}$ & $11.98 \mathrm{a}$ & $11.26 \mathrm{c}$ & $10.96 \mathrm{~d}$ \\
\hline $168 \mathrm{~h}$ & $11.78 \mathrm{a}$ & $11.73 a b$ & $11.95 \mathrm{a}$ & $11.84 \mathrm{a}$ & $11.46 \mathrm{bc}$ & $11.32 \mathrm{c}$ \\
\hline $384 \mathrm{~h}$ & $12.11 \mathrm{ab}$ & $12.09 \mathrm{a}$ & $12.07 \mathrm{ab}$ & $11.91 \mathrm{~b}$ & $11.50 \mathrm{c}$ & $11.35 \mathrm{c}$ \\
\hline \multicolumn{7}{|c|}{ Chemical Oxygen Demand $\left(\mathrm{mg} \cdot \mathrm{L}^{-1}\right)$} \\
\hline $24 \mathrm{~h}$ & $8.0 \mathrm{a}$ & $3.4 \mathrm{a}$ & $0.0 \mathrm{a}$ & $4.6 \mathrm{a}$ & $1.2 \mathrm{a}$ & $1.4 \mathrm{a}$ \\
\hline $72 \mathrm{~h}$ & $10.8 \mathrm{a}$ & $6.1 \mathrm{a}$ & $10.6 \mathrm{a}$ & $8.5 \mathrm{a}$ & $0.1 \mathrm{a}$ & $9.6 \mathrm{a}$ \\
\hline $168 \mathrm{~h}$ & $78.9 \mathrm{a}$ & $67.0 \mathrm{a}$ & $2.4 \mathrm{~b}$ & $26.5 \mathrm{~b}$ & $13.3 \mathrm{~b}$ & $3.3 \mathrm{~b}$ \\
\hline $384 \mathrm{~h}$ & $0.3 \mathrm{a}$ & $16.4 \mathrm{a}$ & $7.1 \mathrm{a}$ & $16.8 \mathrm{a}$ & $3.6 \mathrm{a}$ & $6.1 \mathrm{a}$ \\
\hline \multicolumn{7}{|c|}{ Sulfate $\left(\mathrm{mg} \cdot \mathrm{L}^{-1}\right)$} \\
\hline $24 \mathrm{~h}$ & $21.3 \mathrm{~b}$ & $29.6 \mathrm{~b}$ & $30.0 \mathrm{~b}$ & $22.5 \mathrm{~b}$ & $45.6 \mathrm{~b}$ & $71.7 \mathrm{a}$ \\
\hline $72 \mathrm{~h}$ & $11.0 \mathrm{a}$ & $13.3 \mathrm{a}$ & $18.3 \mathrm{a}$ & $9.3 \mathrm{a}$ & $6.7 \mathrm{a}$ & $11.5 \mathrm{a}$ \\
\hline $168 \mathrm{~h}$ & $9.2 \mathrm{a}$ & $9.8 \mathrm{a}$ & $22.2 \mathrm{a}$ & $8.5 \mathrm{a}$ & $6.1 \mathrm{a}$ & $2.7 \mathrm{a}$ \\
\hline $384 \mathrm{~h}$ & $7.9 \mathrm{a}$ & $8.8 \mathrm{a}$ & $21.6 \mathrm{a}$ & $8.8 \mathrm{a}$ & $8.3 \mathrm{a}$ & $2.4 \mathrm{a}$ \\
\hline \multicolumn{7}{|c|}{ Total Solids $\left(\mathrm{mg} \cdot \mathrm{L}^{-1}\right)$} \\
\hline $24 \mathrm{~h}$ & $320 a b$ & $453 a b$ & $413 \mathrm{a}$ & $352 a b$ & $256 \mathrm{~b}$ & $280 \mathrm{~b}$ \\
\hline $72 \mathrm{~h}$ & $453 a$ & $400 a b c$ & $384 a b$ & $336 \mathrm{bc}$ & $304 \mathrm{bc}$ & $280 \mathrm{c}$ \\
\hline $168 \mathrm{~h}$ & $424 a b$ & 368 bc & $488 \mathrm{a}$ & $432 a b$ & $320 \mathrm{~cd}$ & $264 d$ \\
\hline $384 \mathrm{~h}$ & 336 bc & $408 a b$ & $488 \mathrm{a}$ & $400 \mathrm{ab}$ & $288 \mathrm{bc}$ & $256 \mathrm{c}$ \\
\hline
\end{tabular}

Note: Averages followed by the same letter in a given row did not differ significantly from each other by the Tukey's

test at $5 \%$.

pH

During the first leachate extraction, all the samples presented alkaline character, with $\mathrm{pH}>10.93$ (Table 3). The obtained values are consistent with the alkaline character of concrete; the $\mathrm{pH}$ of concrete pore solution tends to vary from 12.0 to 13.5 [31]. Sani, Fava, Moriconi and Ruello [22] confirmed that for conventional concrete, the leachate $\mathrm{pH}$ ranges from 10.30 to 11.40 during the first $24 \mathrm{~h}$. $\mathrm{pH}$ increases rapidly in the first 100 minutes of contact with deionized water at a temperature of $20 \pm 2{ }^{\circ} \mathrm{C}$; the alkaline character comes from hydroxide and other ions, including $\mathrm{Fe}^{2+}, \mathrm{Ca}^{2+}, \mathrm{Na}^{+}$, and $\mathrm{K}^{+}$[32]. This study assumed 
that the leachate $\mathrm{pH}$ rises as a function of portlandite dissolution, increasing hydroxide and $\mathrm{Ca}^{2+}$ concentration.

Concrete samples RA10 and RA25 exhibited the highest $\mathrm{pH}$ average (Table 3). There was a decrease in these values that was proportional to the higher ceramic content of the concrete. Nonetheless, reductions in $\mathrm{pH}$ values are likely caused by lower contents of cement paste. All the concrete samples were made with the same mass ratio; due to the lower specific mass of the ceramic, there is less cement paste per volume of concrete. The $\mathrm{pH}$ of the leachate maintained its alkalinity throughout the next round of testing. The average $\mathrm{pH}$ value tended to minimally increase as a function of the test time.

It is important to note that in the long term, the leachate $\mathrm{pH}$ tends to drop because of the effect of carbonation on the concrete. This process occurs as a result of $\mathrm{CO}_{2}$ dissolving into the water in the pores most exposed to liquid [33]. Carbonic acid $\left(\mathrm{H}_{2} \mathrm{CO}_{3}\right)$ forms, which, depending on the $\mathrm{pH}$ of the water, dissociates into bicarbonate $\left(\mathrm{HCO}_{3}{ }^{-}\right)$and carbonate $\left(\mathrm{CO}_{3}{ }^{2-}\right)$ ions. The alkaline nature of concrete makes the pore solution susceptible to carbonation [34]. Portlandite is consumed in order to balance the $\mathrm{pH}$ of the concrete pore solution, in line with equation (1). If there is $\mathrm{CO}_{2}$ available, the released calcium will react with the carbonate ions, precipitating $\mathrm{CaCO}_{3}$, according to equation (2) [35].

$$
\begin{gathered}
\mathrm{Ca}(\mathrm{OH})_{2(\mathrm{~s})} \Leftrightarrow \mathrm{Ca}^{2+}{ }_{(\mathrm{aq})}+2 \mathrm{OH}^{-}{ }_{(\mathrm{aq})} \\
\mathrm{Ca}^{2+}{ }_{(\mathrm{aq})}+\mathrm{CO}_{3}^{2-}{ }_{(\mathrm{aq})}=\mathrm{CaCO}_{3(\mathrm{~s})}
\end{gathered}
$$

Concrete carbonation causes the $\mathrm{pH}$ in the pore solution to decline. However, that process can progress slowly in natural environments [34, 36]. As shown in Table 3, this study did not observe drops in $\mathrm{pH}$ during the 16 day leaching test period. This might have resulted from the short test time, which would not have permitted a considerable carbonation process. Additionally, since the concrete remained immersed in water most of the time, it was difficult for $\mathrm{CO}_{2}$ to dissolve in the pore solution.

\section{Total alkalinity}

Leachate total alkalinity ranged from 99.6 to $273.0 \mathrm{mg}$ of $\mathrm{CaCO}_{3} \mathrm{~L}^{-1}$ (Fig. 1), corresponding to the values of RA100 and NABO, respectively. The dissolution of $\mathrm{Ca}(\mathrm{OH})_{2}$ in the cement paste is also responsible for concrete leachate alkalinity, as confirmed by the lower total alkalinity levels in concrete with smaller quantities of cement paste.

As opposed to the other treatments, the average alkalinity of the leachate for NABO and RCA dropped over the 16-day trial.

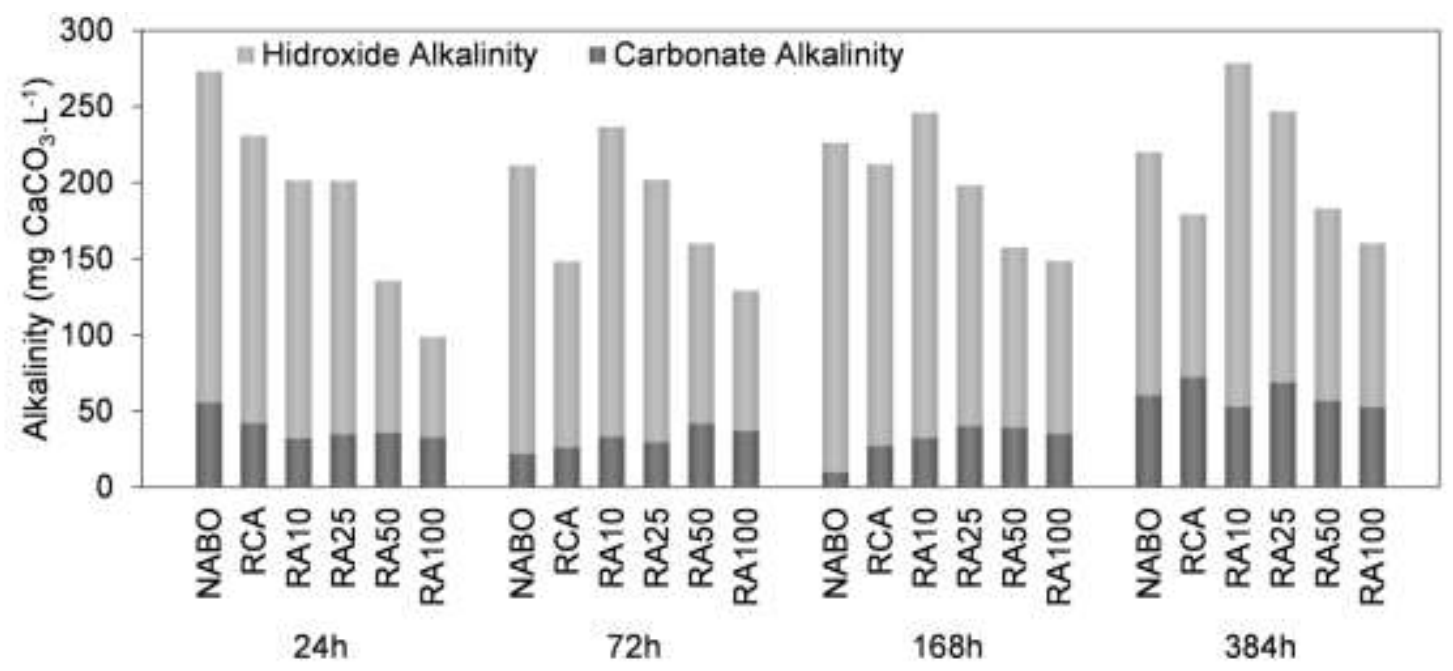

Figure 1. Composition of the leachate total alkalinity for the different permeable concretes as a function of test time

Despite variability in the alkalinity results, Figure 1 shows a tendency toward decreasing alkalinity between the RA10 and RA100 treatments. This was attributed to the different quantities of cement per volume of concrete. The NABO and RCA treatments presented intermediate values, which may have been caused by their different materials, namely natural aggregate and crushed concrete, respectively. On the 
other hand, the RA10 and RA25 treatments exhibited higher alkalinity than the concrete samples. This is due to the presence of old concrete fragments, which were already subject to carbonation.

Most of the alkalinity in the leachate was the result of the presence of hydroxide (Fig. 1). The amount of hydroxide was smaller for the RA50 and RA100 treatments, which can be explained by the smaller quantities of cement paste in those samples. NABO and RCA yielded similar physical characteristics, but NABO released more hydroxide in all four time intervals. This was likely the result of the greater pore volume when compared to the concrete used for RCA, which could have interfered with the leaching of the compounds in the cement paste.

\section{Electrical conductivity}

The average values of electrical conductivity varied from 278.1 to $625.3 \mu \mathrm{S} \mathrm{cm} \mathrm{cm}^{-1}$ for the first leachate extraction. Figure 2 shows that the NABO treatment had higher electrical conductivity than the RCA, RA50, and RA100 treatments. The inclusion of recycled aggregates in pervious concrete did not result in a higher ion concentration. This can be attributed to cement paste leaching, as the process begins at the surface of the material, with dissolved compounds migrating to the exterior [28]. There was a tendency toward decreasing electrical conductivity with increasing ceramic material, according to Figure 2.

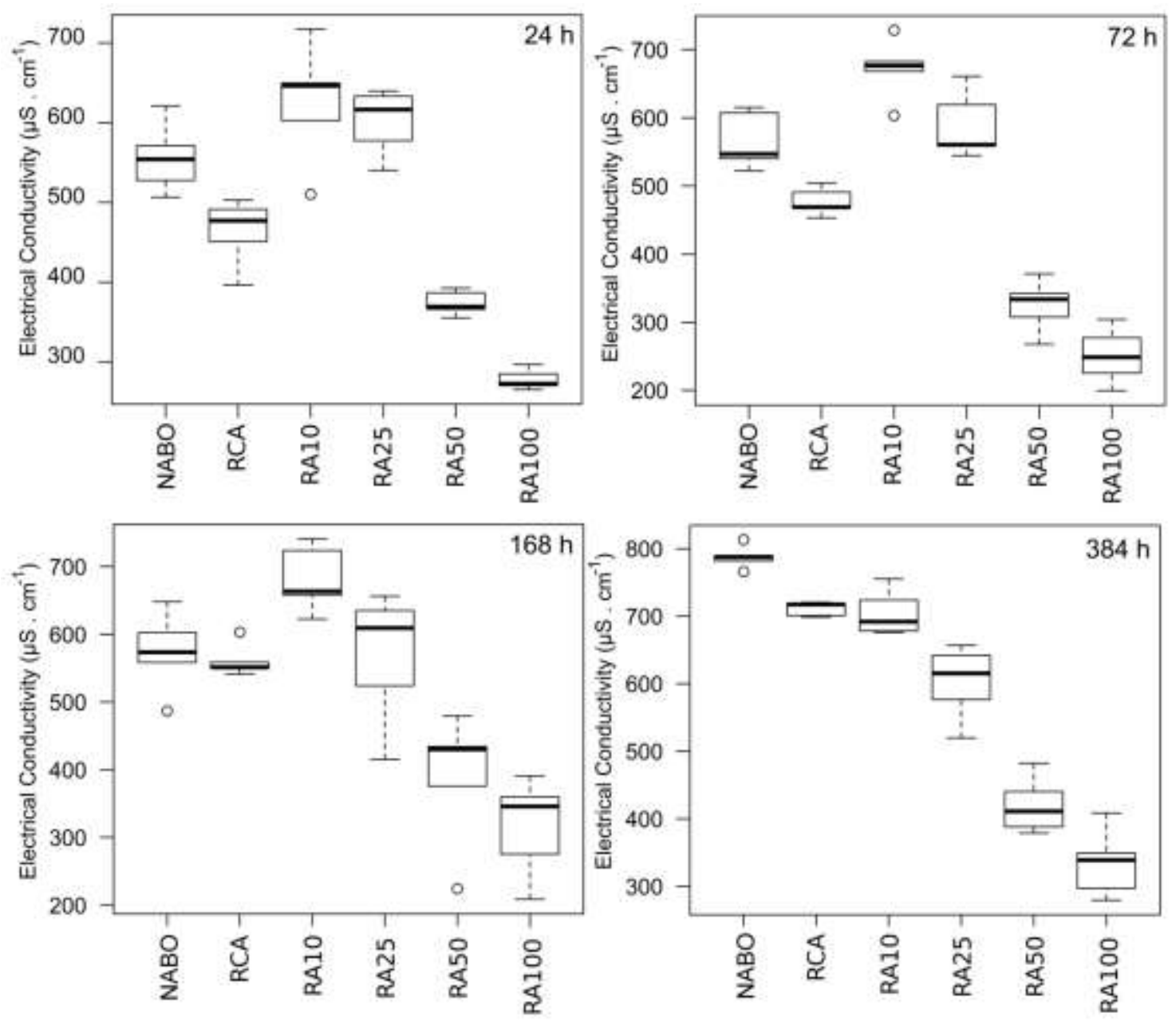

Figure 2. Variation of electrical conductivity values in the samples after $24,72,168$, and $384 \mathrm{~h}$, as a function of the kind of aggregate used for the pervious concrete

Electrical conductivity rose after 72,168 , and $384 \mathrm{~h}$, except in the RA25 treatment (Fig. 2). This reveals that the leaching process of the concrete is continuous, with a release of compounds in the cement paste proportional to the amount of time of contact with water. Mehta and Monteiro [27] affirm that, in theory, the leaching of $\mathrm{Ca}(\mathrm{OH})_{2}$ from cement paste would continue until its total elimination, leaving the other compounds in the concrete susceptible to leaching.

The RA10 and RA100 treatments demonstrated the same tendency in all four time intervals, with a decline in conductivity proportional to increases in ceramic content (Fig. 2). 
COD

COD in the concrete leachate was lower than $8.0 \mathrm{mg} \mathrm{L}^{-1}$ for the first $24 \mathrm{~h}$ of leaching (Table 3 ). The obtained results were justified by the lack of organic matter from the concrete and its constituents, except in cases where the aggregate was contaminated. There was no direct relation between the kind of aggregate used or the amount of ceramic and COD.

In the same way, no relation was established between COD and the kind of aggregate used to produce the concrete samples. Likewise, COD showed no relation to elapsed time. In the extraction after $168 \mathrm{~h}$, NABO and RCA treatments showed values significantly higher than the other samples. This could be the result of either sample contamination or errors in the experimental procedure. Additionally, the presence of ions like $\mathrm{Fe}^{2+}$ could have influenced the results, as described by the Standard Methods for the Examination of Water and Wastewater [25].

\section{Sulfate}

Concrete RA100 leached $71.7 \mathrm{mg} \mathrm{L}^{-1}$ of sulfate after $24 \mathrm{~h}$ of contact with water, which corresponded to the highest value among the treatments (Table 3). Nonetheless, this value is under the limit of $250 \mathrm{mg} \mathrm{L}^{-1}$, as established by Italian methodology [24]. Concentrations are also below the maximum limit fixed by Brazilian standard NBR 10004 [37]. Unlike pH, EC, and alkalinity, the amount of sulfate released was dependent on the quantity of ceramic material in the concrete. This was confirmed by studies that verified higher concentrations of sulfate in the leachate of waste containing higher quantities of ceramic [38]. However, RCA concrete also discharged significant amounts of $\mathrm{SO}_{4}{ }^{2-}$. Mortar in the fragments of recycled aggregate is also responsible for sulfate leaching [19].

Sulfate concentrations were lower in the 72 -h extraction, with a reduction of more than $50 \%$ in all treatments. Concentrations decreased up until the last extraction, demonstrating that the first contact between concrete and water is most critical with respect to $\mathrm{SO}_{4}{ }^{2-}$ leaching. After the second extraction, the RA10 treatment showed higher concentrations than the others. This was caused by sample contamination with gypsum fragments, which were observed and distinguished by the color of the material in the sample. Gypsum is also responsible for the presence of sulfate in CDW [19, 38].

\section{Total solids}

Total solids concentrations were between 280 and $453 \mathrm{mg} \mathrm{L}^{-1}$ for the first leachate extraction (Table 3). Between 67.6 and $80.8 \%$ of total solids consisted of fixed solids, which resulted from the dissolution of inorganic compounds in the concrete. Once again, total solids tended to decrease with increasing ceramic material.

More generally, leachate total solids concentrations tended to increase. This occurred because of constant leaching of the compounds in the cement paste.

\section{Heavy metals}

Of the heavy metals that were analyzed, only chromium and cadmium were identified (Fig. 3A). There was variation in the release of metals as a function of both test time and ceramic content in the aggregate.
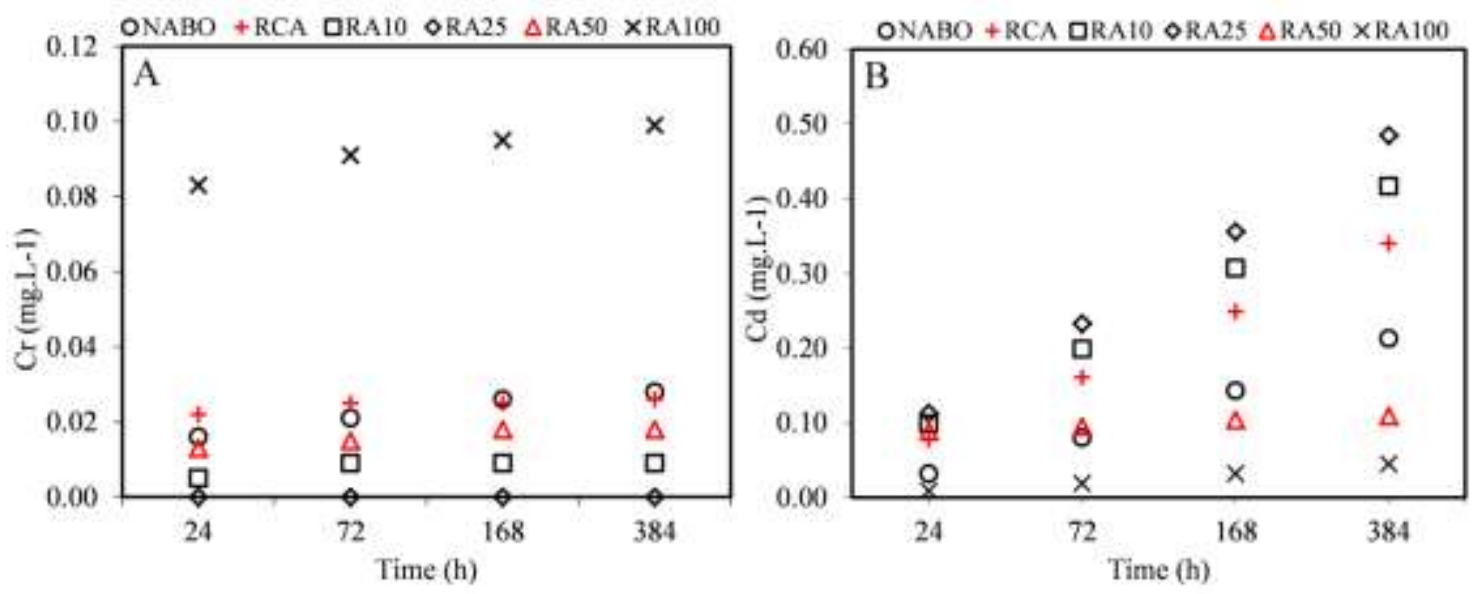
Figure 3. Average cumulative concentrations of (a) chromium and (b) cadmium in pervious concrete leachate as a function of the type of aggregate used, over the course of the 16-day leaching test period

Chromium was found in all the leachate treatments with the exception of RA25 (Fig. 3A). RA100 gave the highest concentration of $\mathrm{Cr}$, with about $0.083 \mathrm{mg} \mathrm{L}^{-1}$ in the extraction after 24 hours. Concrete produced with natural aggregates also leached chromium, but in smaller quantities. The higher chromium concentration in the RA100 treatment can be explained by the presence of the element in ceramic material. Cr leaching of up to $4.266 \mathrm{mg} \mathrm{kg}^{-1}$ was already observed in ceramic materials [19]. However, cement is partly responsible for this effect [17]. Milanez, Fernandes and Porto [39] indicated that metals such as chromium can be present in the clinker during cement manufacturing due to impurities in the raw materials and fuels used.

After $72 \mathrm{~h}$, there was very little increase in $\mathrm{Cr}$ concentrations, with the exception of RA100, which continued releasing larger amounts. After 168 and $384 \mathrm{~h}$, cumulative $\mathrm{Cr}$ concentrations leveled out. Chromium leaching was more notable in the first $24 \mathrm{~h}$ after contact with water. According to Italian methodology [24], only the RA100 treatment exceeded the Cr limit of $0.050 \mathrm{mg} \mathrm{L}^{-1}$.

A rapid release of cadmium was observed in the first $24 \mathrm{~h}$ of testing. All the treatments, including concrete that contained natural aggregate, exceeded the limit of $0.005 \mathrm{mg} \mathrm{L}^{-1}$ established by Italian methodology [24]. Unlike with chromium, cadmium leaching was not defined by ceramic content. This was confirmed by the more limited leaching of the element in the RA100 treatment. There were higher concentrations in the samples containing greater amounts of CDW and crushed concrete, suggesting that cement paste and recycled aggregates play a major role.

The release of cadmium was still observed in extractions after 72,168 , and $384 \mathrm{~h}$, increasing accumulated concentrations to a high of $0.485 \mathrm{mg} \mathrm{L}^{-1}$ for the RA25 sample. This concentration is high, so much so that it is up to 100 times greater than the limit of the methodology. Given the circumstances, it is expected that cadmium leaching would continue, resulting in even higher concentrations. Figure 3B shows cadmium concentrations increasing over time. This can be the result of cadmium being encapsulated in the cement matrix, allowing it to be released during the leaching of the portlandite [26].

Copper, lead, and zinc were not found in the leachate. This can be explained by the leachate $\mathrm{pH}$; with $\mathrm{pH}$ levels of 10 to 12 , the leaching of these elements is minimal [40]. They could be detected with pH levels lower than 6.

\section{CONCLUSION}

Recycled aggregates can be used to produce pervious concrete on a limited scale. The substitution of natural aggregates with RCA did not cause significant changes in the physicochemical properties of the water. However, cadmium release from concrete containing concrete waste was $56 \%$ higher.

Concrete containing mixed recycled aggregates presented decreased specific mass with increasing ceramic material content. As a consequence, $\mathrm{pH}$, electrical conductivity, alkalinity, and total solids in the leachate declined as ceramic content rose.

Sulfate and chromium release were highest in the concrete containing $100 \%$ ceramic aggregate. Nonetheless, cadmium release for this material was minimal.

The presence of chromium and cadmium in the leachate will limit the extent to which CDW can be used as an aggregate, since the detected concentrations of these metals exceeded the limit set by the methodology. Sulfate concentration did not exceed the limit established by Brazilian standards.

This study verified that conventional pervious concrete alters water quality and that the replacement of the aggregates with CDW has an even greater impact.

Funding: This research received no external funding.

Acknowledgments: The authors thank C-LABMU/UEPG for their support and for performing atomic absorption spectrometry.

Conflicts of Interest: The authors declare no conflict of interest.

\section{REFERENCES}

1. Butera S, Hyks J, Christensen TH, Astrup TF. Construction and demolition waste: Comparison of standard upflow column and down-flow lysimeter leaching tests. Waste Manag. 2015;43:386-97.

2. ABRELPE [Brazilian Association of Public Cleaning and Special Waste Companies]. Panorama dos resíduos sólidos no Brasil [Overview of solid waste in Brazil]. São Paulo: ABRELPE; 2014. 120 p. 
3. CONAMA. Resolução CONAMA n $n^{\circ}$ 307. [Establishes guidelines, criteria and procedures for the management of construction waste]. 136 Brasil: Diário Oficial da União; 2002 p. 95-6.

4. Morales G, Jungles AE, Klein SES, Guarda J. Ei scale - an environmental impact assessment scale related to the construction materials used in the reinforced concrete. Brazilian Arch Biol Technol. 2010;53(6):1511-8.

5. Behera M, Bhattacharyya SK, Minocha a. K, Deoliya R, Maiti S. Recycled aggregate from C\&D waste \& its use in concrete - A breakthrough towards sustainability in construction sector: A review. Constr Build Mater. 2014;68:501-16.

6. Dahlbo H, Bachér J, Lähtinen K, Jouttijärvi T, Suoheimo P, Mattila T, et al. Construction and demolition waste management - A holistic evaluation of environmental performance. J Clean Prod. 2015;107:333-41.

7. Rodríguez G, Medina C, Alegre FJ, Asensio E, De Sánchez Rojas MI. Assessment of Construction and Demolition Waste plant management in Spain: In pursuit of sustainability and eco-efficiency. J Clean Prod. 2015;90:16-24.

8. ABRECON [Brazilian Association for Recycling of Construction and Demolition Waste]. Pesquisa Setorial 2014/2015 [Sectoral research 2014/2015]. São Paulo: ABRECON; 2015. 30 p.

9. Vieira CS, Pereira PM. Use of recycled construction and demolition materials in geotechnical applications: A review. Resour Conserv Recycl. 2015 Oct;103:192-204.

10. Puthussery J V., Kumar R, Garg A. Evaluation of recycled concrete aggregates for their suitability in construction activities: An experimental study. Waste Manag. 2017 Feb;60:270-6.

11. Ibrahim A, Mahmoud E, Yamin M, Patibandla VC. Experimental study on Portland cement pervious concrete mechanical and hydrological properties. Constr Build Mater. 2014;50:524-9.

12. American Concrete Institute. ACl 522R-10 Report on Pervious Concrete. Farmington Hills: American Concrete Institute; 2010. 42 p.

13. Tennis PD, Leming ML, Akers DJ. Pervious Concrete Pavements. Portland Cement Association, Skokie, Illinois, and National Ready Mixed Concrete Association, Silver Spring, Maryland, USA. 2004. 36 pages.

14. Crouch LK, Pitt J, Hewitt R. Aggregate Effects on Pervious Portland Cement Concrete Static Modulus of Elasticity. J Mater Civ Eng. 2007;19(July):561-8.

15. Ramezanianpour AA, Joshaghani A. Mechanical Characteristic of Pervious Concrete Considering the Gradation and Size of Coarse Aggregates. Res. J. Environ. Earth Sci. 2015;6(9):1-14.

16. Fu TC, Yeih W, Chang JJ, Huang R. The influence of aggregate size and binder material on the properties of pervious concrete. Adv Mater Sci Eng. 2014;2014.

17. Galvín AP, Ayuso J, García I, Jiménez JR, Gutiérrez F. The effect of compaction on the leaching and pollutant emission time of recycled aggregates from construction and demolition waste. J Clean Prod. 2014;83:294-304.

18. Jacob JDS, Rocha JC, Cheriaf M. [Analysis of leaching of heavy metals in concretes produced with recycled aggregates]. In: V Encontro Nacional e III Encontro Latino-Americano sobre Edificações e Comunidades Sustentáveis. Recife; 2009. p. 1-10.

19. Del Rey I, Ayuso J, Galvín AP, Jiménez JR, López M, García-Garrido ML. Analysis of chromium and sulphate origins in construction recycled materials based on leaching test results. Waste Manag. 2015 Dec;46:278-86.

20. Schiopu N, Tiruta-Barna L, Jayr E, Méhu J, Moszkowicz P. Modelling and simulation of concrete leaching under outdoor exposure conditions. Sci Total Environ. 2009 Feb;407(5):1613-30.

21. Saravanan MM, Sivaraja M. Mechanical behavior of concrete modified by replacement of cement by rice husk ash. Brazilian Arch Biol Technol. 2016;59(2 SPEC. ISS):1-11.

22. Sani D, Moriconi G, Fava G, Corinaldesi V. Leaching and mechanical behaviour of concrete manufactured with recycled aggregates. Waste Manag. 2005;25(2 SPEC. ISS.):177-82.

23. Corinaldesi V, Fava G, Moriconi G, Ruello ML. Biomass ash and its use in concrete mixture. Excell Concr Constr through Innov. 2009;245-50.

24. DMA 5 febbraio. [Identification of non-hazardous waste subject to simplified recovery procedures pursuant to Articles 31 and 33 of the Legislative Decree of 5 February 1997, n . 22] . Italy: Supplemento ordinario alla Gazzetta Ufficiale n 88 del 16 aprile 1998.; 1998 p. 1-67.

25. APHA, AWWA, WEF. Standard Methods for the Examination of Water and Wastewater. 21st ed. Washington; 2005.

26. Halim CE, Amal R, Beydoun D, Scott JA, Low G. Implications of the structure of cementitious wastes containing $\mathrm{Pb}(\mathrm{II}), \mathrm{Cd}(\mathrm{II}), \mathrm{As}(\mathrm{V})$, and $\mathrm{Cr}(\mathrm{VI})$ on the leaching of metals. Cem Concr Res. 2004;34(7):1093-102.

27. Mehta PK, Monteiro PJM. [Concrete: Microstructure, properties and materials]. São Paulo: IBRACON; 2008. 573 p.

28. Jebli M, Jamin F, Garcia-Diaz E, El Omari M, El Youssoufi MS. Influence of leaching on the local mechanical properties of an aggregate-cement paste composite. Cem Concr Compos. 2016;73:241-50. 
29. Rozière E, Loukili A, El Hachem R, Grondin F. Durability of concrete exposed to leaching and external sulphate attacks. Cem Concr Res. 2009;39(12):1188-98.

30. Ulm F-J, Lemarchand E, Heukamp FH. Elements of chemomechanics of calcium leaching of cement-based materials at different scales. Eng Fract Mech. 2003 May;70(7-8):871-89.

31. Demir $F$, Yesilata $B$, Turgut $P$, Bulut $H$, Isiker $Y$. Investigation of the effects of $p H$, aging and scrap tire content on the dissolution behaviors of new scrap tire-concrete mixture structures. J Clean Prod. 2015;93:38-46.

32. Jung MS, Hwang JP, Kim JH, Lee CK, Ann KY. Risk of environmental contamination arising from concrete structures, Part III: Alkali leaching. KSCE J Civ Eng. 2015 Sep;19(6):1597-603.

33. Engelsen CJ, Wibetoe G, van der Sloot HA, Lund W, Petkovic G. Field site leaching from recycled concrete aggregates applied as sub-base material in road construction. Sci Total Environ. 2012;427-428:86-97.

34. Gervais C, Garrabrants AC, Sanchez F, Barna R, Moszkowicz P, Kosson DS. The effects of carbonation and drying during intermittent leaching on the release of inorganic constituents from a cement-based matrix. Cem Concr Res. 2004;34(1):119-31.

35. Engelsen CJ, van der Sloot HA, Petkovic G. Long-term leaching from recycled concrete aggregates applied as sub-base material in road construction. Sci Total Environ. 2017 Jun;587-588:94-101.

36. Müllauer W, Beddoe RE, Heinz D. Effect of carbonation, chloride and external sulphates on the leaching behaviour of major and trace elements from concrete. Cem Concr Compos. 2012;34(5):618-26.

37. ABNT [Brazilian Association of Technical Standards]. NBR 10004 - Resíduos Sólidos - Classificação [NBR 10004 - Solid waste - Classification]. Rio de Janeiro: ABNT; 2004. 71 p.

38. Barbudo A, Galvín AP, Agrela F, Ayuso J, Jiménez JR. Correlation analysis between sulphate content and leaching of sulphates in recycled aggregates from construction and demolition wastes. Waste Manag. 2012;32(6):1229-35.

39. Milanez B, Fernandes LDO, Porto MFDS. [Coincineration of waste in cement kilns: risks to health and the environment]. Cien Saude Colet. 2009;14(6):2143-52.

40. Engelsen CJ, Van Der Sloot HA, Wibetoe G, Justnes H, Lund W, Stoltenberg-Hansson E. Leaching characterisation and geochemical modelling of minor and trace elements released from recycled concrete aggregates. Cem Concr Res. 2010;40(12):1639-49.

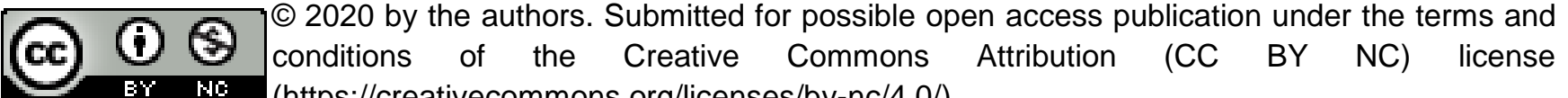
(https://creativecommons.org/licenses/by-nc/4.0/). 